\title{
A Novel Liquid Multi-Phytonutrient Supplement Demonstrates DNA-Protective Effects
}

\author{
Benjamin J. Baechler • Florina Nita $\cdot$ Lon Jones • \\ Joy L. Frestedt
}

Published online: 3 March 2009

(C) The Author(s) 2009. This article is published with open access at Springerlink.com

\begin{abstract}
This study explored the DNA protective (antimutagenic) effects of an oral, liquid, multi-phytonutrient dietary supplement containing a proprietary blend of fruits, vegetables and aloe vera concentrated components in addition to a proprietary catechin complex from green tea (VIBE Cardiac \& Life, Eniva Nutraceuticals, Anoka, $\mathrm{MN}$; herein described as "VIBE"). This study tested the hypothesis that VIBE would reduce DNA damage in skin cells exposed to UVR. Human epidermal cells, from the cell line A431NS, were treated with $0 \%$ (control), $0.125 \%$, $0.5 \%, 1 \%$ and $2 \%$ VIBE, and then exposed to $240 \mathrm{~J} / \mathrm{m}^{2}$ UVR. The amount of DNA damage was assessed using the COMET assay. At each concentration tested, a significantly smaller amount of DNA damage was measured by the COMET assay for the VIBE treated cells compared to the control cells exposed to UVR without VIBE. The dose response curves showed a maximal response at $0.5 \% \mathrm{VIBE}$ with a threefold reduction in COMET tail density compared to the control samples without VIBE $(p<0.001)$. Additional research is warranted in human clinical trials to further
\end{abstract}

\author{
B. J. Baechler $\cdot$ F. Nita $\cdot$ L. Jones \\ Eniva Nutraceuticals, \\ Blaine, MN 55434, USA \\ B. J. Baechler \\ e-mail: baec0004@umn.edu \\ F. Nita \\ e-mail: florinan@eniva.com \\ L. Jones \\ e-mail: lonj@eniva.com \\ J. L. Frestedt $(\bowtie)$ \\ Frestedt Incorporated, \\ 2708 Vernon Ave S, \\ St. Louis Park, MN 55416, USA \\ e-mail: jf@frestedt.com
}

explore the results of this study which demonstrated the DNA protective and anti-mutagenic effects of VIBE for human skin cells exposed to UVR-induced DNA damage.

Keywords Anti-mutagenic - COMET assay .

Epidermal cells · Green tea (-)-epigallocatechin-3-gallate (EGCG) $\cdot$ Phytonutrient supplement $\cdot$ UV genotoxicity
Abbreviations
DNA deoxyribonucleic acids
EGCG epigallocatechin-3-gallate
LMP low melting point
UVR ultraviolet radiation

\section{Introduction}

Cellular stress leading to deoxyribonucleic acid (DNA) damage and genetic mutation may result in uncontrolled, pro-carcinogenic cellular proliferation. One agent known to induce carcinogenic changes in human skin cells is ultraviolet radiation (UVR). Although the exact mechanism whereby UVR exposure results in skin cancer remains unclear, UVR exposure is known to generate free radicals and DNA strand breaks which contribute to pro-carcinogenic cascades potentially leading to cancer [1-3]. The catechin, (-)-epigallocatechin-3-gallate (EGCG) has been shown to protect against UVR-induced skin and DNA damage, and may provide protection against the development of skin and other cancers [4-11]. One study demonstrated EGCG provided concentration-dependent protection against UVRinduced DNA damage in cultured human skin fibroblasts and epidermal keratinocytes. This study also demonstrated that consumption of green tea (which is a rich dietary 
source of EGCG) reduced the amount of DNA damage in blood cells of human subjects exposed to UVR [12].

This study tested the hypothesis that a liquid nutritional supplement containing essential nutrients, a proprietary blend of plant components and a proprietary green tea catechin complex including EGCG (VIBE 2.0 Cardiac \& Life; Eniva Nutraceuticals, Anoka, MN) was able to reduce DNA damage in human skin cells exposed to UVR. We used the COMET assay [single-cell gel electrophoresis (SCGE)] [13] to measure the DNA protective and antimutagenic properties of an in vitro treatment with VIBE for epidermal cells exposed to UVR. The COMET assay is widely used in environmental toxicology, cancer research, and radiation biology as a sensitive and broadly accepted method for measuring DNA damage in individual cells. Briefly, cells are embedded in agarose gel on a microscope slide, lysed, electrophoresed, and stained with fluorescent DNA-binding dye. DNA from each cell migrates towards the anode during electrophoresis forming a shape of a "COMET" with a head (cell nucleus with intact DNA) and a tail (relaxed and broken DNA). The DNA percentage in the COMET tail (tail density) was the study endpoint since cells with damaged DNA have increased COMET tail density.

\section{Materials and Methods}

Cell Line The human epidermoid cell line, A413NS (American Type Culture Collection, Manassas, VA) was maintained in RPMI 1640 with $10 \%$ calf serum and $2 \mathrm{mM}$ glutamine.

Test Article The liquid multi-phytonutrient dietary supplement containing essential nutrients, a proprietary blend of fruits, vegetables and aloe vera gel concentrated components, and a proprietary green tea EGCG catechin complex (VIBE 2.0 Cardiac \& Life; Eniva Nutraceuticals, Anoka, MN; Table 1), was mixed with freshly prepared RPMI 1640 growth medium $(10 \%, v / v)$.

UVR Treatment A germicidal lamp with a spectrum peak at $254 \mathrm{~nm}$ was used as the radiation source, and a $240 \mathrm{~J} / \mathrm{m}^{2}$ energy equivalent was delivered at the surface of the cell culture medium.

Cell Viability Assay Viability was analyzed after test article treatment and 15 min of recovery after irradiation (Guava ViaCount Assay, Guava Technologies, Inc., Hayword, CA).

COMET Assay Cells were grown in 24-well plates until $60-80 \%$ confluent, then treated with $0 \%$ (positive and negative controls), $0.125 \%, 0.25 \%, 0.5 \%, 1.0 \%$, and $2.0 \%$
VIBE for $30 \mathrm{~min}$ in duplicate. The treatment medium was replaced with $100 \mu \mathrm{l}$ of fresh medium (without VIBE), and cells were exposed to $240 \mathrm{~J} / \mathrm{m}^{2}$ UVR ("negative" controls were covered with aluminum foil to prevent exposure to UVR while "positive" controls were exposed directly to UVR). Cells were incubated $15 \mathrm{~min}$ to allow recovery, washed with Dulbecco's phosphate buffered saline and trypsinized to obtain a single cell suspension. An aliquot of

Table 1 Supplement facts for VIBE 2.0 cardiac and life

\begin{tabular}{|c|c|c|}
\hline & $\begin{array}{l}\text { Amount per } \\
\text { serving }^{\mathrm{a}}\end{array}$ & $\begin{array}{l}\% \text { Daily } \\
\text { value }^{\mathrm{a}}\end{array}$ \\
\hline Calories & \multicolumn{2}{|l|}{30} \\
\hline Total Carbohydrate & \multicolumn{2}{|l|}{$6 \mathrm{~g}$} \\
\hline Sugars & \multicolumn{2}{|l|}{$4 \mathrm{~g}$} \\
\hline Vitamin A & \multicolumn{2}{|l|}{ 2,000 IU } \\
\hline Vitamin $\mathrm{C}$ & \multicolumn{2}{|l|}{$120 \mathrm{mg}$} \\
\hline Vitamin D & \multicolumn{2}{|l|}{$500 \mathrm{IU}$} \\
\hline Vitamin E & \multicolumn{2}{|l|}{$30 \mathrm{IU}$} \\
\hline Thiamin (Vitamin B1) & \multicolumn{2}{|l|}{$1.5 \mathrm{mg}$} \\
\hline Riboflavin (Vitamin B2) & \multicolumn{2}{|l|}{$1.7 \mathrm{mg}$} \\
\hline Niacin & \multicolumn{2}{|l|}{$18 \mathrm{mg}$} \\
\hline Vitamin B6 & \multicolumn{2}{|l|}{$2 \mathrm{mg}$} \\
\hline Folic Acid & \multicolumn{2}{|l|}{$400 \mathrm{mcg}$} \\
\hline Vitamin B12 & \multicolumn{2}{|l|}{$12 \mathrm{mcg}$} \\
\hline Biotin & \multicolumn{2}{|l|}{$300 \mathrm{mcg}$} \\
\hline Pantothenic Acid & \multicolumn{2}{|l|}{$10 \mathrm{mg}$} \\
\hline Calcium & \multicolumn{2}{|l|}{$100 \mathrm{mg}$} \\
\hline Phosphorus & \multicolumn{2}{|l|}{$20 \mathrm{mg}$} \\
\hline Iodine & \multicolumn{2}{|l|}{$150 \mathrm{mcg}$} \\
\hline Magnesium & \multicolumn{2}{|l|}{$155 \mathrm{mg}$} \\
\hline Zinc & \multicolumn{2}{|l|}{$5 \mathrm{mg}$} \\
\hline Selenium & \multicolumn{2}{|l|}{$25 \mathrm{mcg}$} \\
\hline Copper & \multicolumn{2}{|l|}{$0.5 \mathrm{mg}$} \\
\hline Manganese & \multicolumn{2}{|l|}{$1.8 \mathrm{mg}$} \\
\hline Chromium & \multicolumn{2}{|l|}{$120 \mathrm{mcg}$} \\
\hline Potassium & \multicolumn{2}{|l|}{$175 \mathrm{mg}$} \\
\hline Proprietary trace mineral blend & \multicolumn{2}{|l|}{$37 \mathrm{mg}$} \\
\hline Boron, germanium, sulfur, vana & \\
\hline AntiOX $^{2}\left({ }^{\circledR}\right.$ proprietary blend & $6,500 \mathrm{mg}$ & $-^{\mathrm{b}}$ \\
\hline \multicolumn{3}{|c|}{$\begin{array}{l}\text { Natural extracts: green tea, cranberry, raspberry, blueberry, blackberry } \\
\text { strawberry, cherry, carrot, acai berry, elderberry, hibiscus (flower), } \\
\text { lemon, lime, apple, orange, blackcurrant, oregano, chokeberry, grape } \\
\text { pumpkin, tomato, pomegranate, wolfberry (gojiberry), Stevia (leaf), } \\
\text { grape seed extract, citrus bioflavonoids }\end{array}$} \\
\hline HeartPRO ${ }^{\circledR}$ proprietary blend & \multicolumn{2}{|c|}{$280 \mathrm{mg} \quad-\mathrm{b}$} \\
\hline \multicolumn{3}{|c|}{$\begin{array}{l}\text { D-Ribose, CoQ10, L-carnitine, malic acid, isolated soy lecithin, mixe } \\
\text { tocopherols }\end{array}$} \\
\hline CollaMAX ${ }^{\circledR}$ proprietary blend & $3,500 \mathrm{mg}$ & $-^{\mathrm{b}}$ \\
\hline $\begin{array}{l}\text { Green tea leaf extract (water de } \\
\text { vera gel (containing alanine, v } \\
\text { glucosamine } \mathrm{HCl} \text { (vegetable) }\end{array}$ & $\begin{array}{l}\text { inated), 1-lysin } \\
\text { isoleucine, gl }\end{array}$ & $\begin{array}{l}\text { roline, aloe } \\
\text {, leucine), }\end{array}$ \\
\hline
\end{tabular}

${ }^{\text {a }}$ Percent daily values are based on a 2,000 calorie diet and a one fluid ounce serving

${ }^{\mathrm{b}}$ Daily value not established 


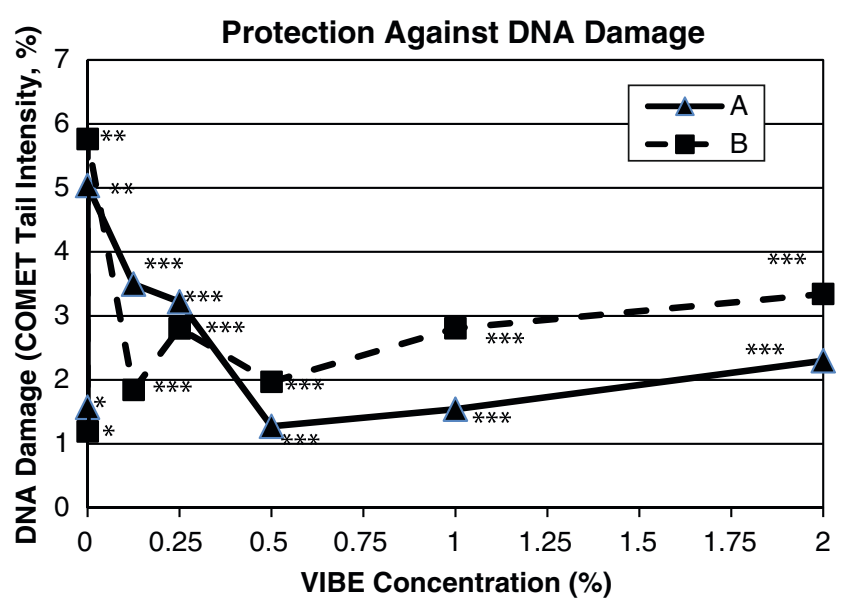

Fig. 1 VIBE provides protection against DNA damage in human epidermal cells exposed to UVR. Two independent experiments $(A$ and $B$ ) confirm the DNA protection provided by VIBE as measured by mean COMET tail density. The negative control (asterisk) was not exposed to UVR and did not contain any VIBE. The positive control (two asterisks) was exposed to UVR and did not contain any VIBE. All test samples with increasing concentrations of VIBE were exposed to the same amount of UVR as the positive control and showed a significantly lower amount of DNA damage compared to the positive control (three asterisks; $p<0.001$ )

10,000 to 20,000 cells were centrifuged $(400 \times g$ for $5 \mathrm{~min}$ ), mixed with $0.5 \%$ low melting point (LMP) agarose (in PBS at $37{ }^{\circ} \mathrm{C}$ ), laid on an agarose-coated microscopic slide and covered with a cover glass. The slide was chilled $20 \mathrm{~min}$ and the cover glass was removed. Another layer of $70 \mu \mathrm{l}$ LMP agarose was added above the cell-containing layer and spread thin by the addition of another cover glass and chilled. After the agarose gel hardened, the coverglass was removed and the slide was immersed in cold lysing solution overnight. The slide was placed in a horizontal gel electrophoresis tank and electrophoresed at $25 \mathrm{~V}$ for $20 \mathrm{~min}$. The slide was rinsed, stained with ethidium bromide $(60 \mu \mathrm{l}$, $20 \mu \mathrm{g} / \mathrm{ml}$ ) and immediately scored using a 40-power objective with G-2A filter of a Nikon E400 fluorescence microscope equipped with a COMET III Image System (Perceptive Instruments Ltd, Haverhill, Suffolk, UK). Fifty cells from each duplicate slide were scored for tail density (percentage of DNA in the COMET tail) and this entire method was repeated for a second, independent confirmation of the experimental data.

Fig. 2 Representative photograph of a negative control sample with no mutagen (UVR) exposure (two cells)

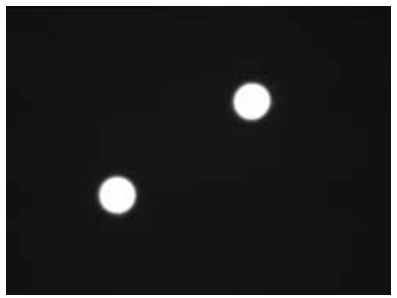

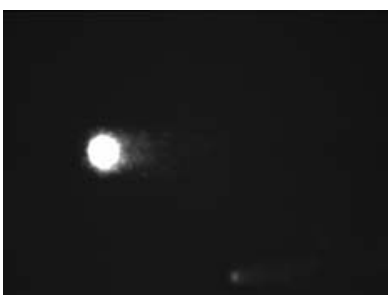

Fig. 3 Representative photograph of a positive control cell showing the increased DNA density in the COMET tail after mutagen (UVR) exposure without VIBE (i.e. no DNA protective effect was evident since VIBE was not included in this sample)

Statistics The non-parametric Mann-Whitney test was used to compare the UVR exposed VIBE-treated cells with the UVR exposed untreated (positive) control cells.

\section{Results}

Cell viability remained above $94.5 \%$ for all samples and cells treated with increasing concentrations of VIBE showed significantly smaller amounts of DNA damage, as measured by COMET tail density compared to the positive control cells exposed to UVR ( $p<0.001$, Fig. 1). Representative photographs (Figs. 2, 3 and 4) show the varying intensities of the COMET tails produced in this study. The negative control sample (Fig. 2) included cells not exposed to the UVR mutagen and showed the smallest COMET tail density compared to the positive control sample (Fig. 3cells exposed to the UVR mutagen without any VIBE treatment) which showed the greatest COMET tail density. The test sample (Fig. 4c) included cells treated with $0.5 \%$ VIBE and showed a significantly smaller amount of COMET tail density compared to the positive control (Fig. 4 compared to Fig. 3).

\section{Discussion}

The results of this study show that multi-phytonutrient dietary supplement, VIBE, reduced DNA damage and

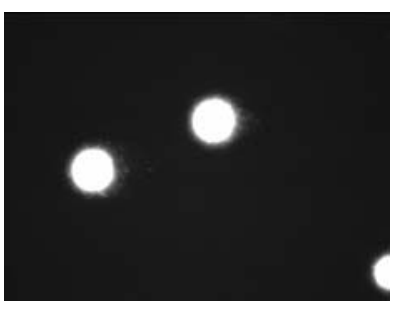

Fig. 4 Representative photograph of the anti-mutagenic effects of $0.5 \%$ VIBE in two cells showing the decreased (compared to Fig. 3 ) DNA density in the COMET tail after mutagen (UVR) exposure when cells were treated with VIBE (i.e. a significant DNA protective effect was evident with the VIBE treatment) 
genotoxicity as measured in the COMET assay using human epidermal skin cells exposed to ultraviolet radiation. VIBE contains a broad spectrum antioxidant complex from fruits, vegetables, aloe vera gel and green tea, and the potential mechanisms behind these DNA protective properties may be related to the antioxidant activities of one or more of these antioxidant ingredients [14]. In this study, two independent COMET assays demonstrated significantly reduced amounts of DNA migrating in the COMET tails among the VIBE-treated cells compared to the amount of DNA in the COMET tails of the positive control cells exposed to UVR without VIBE (at all concentrations tested, all comparisons were $p<0.001$, Fig. 1). These data suggest that VIBE promoted genetic stability and thus had antimutagenic activity in skin cells exposed to ultraviolet radiation, a common pro-carcinogenic agent with significant human exposures. These effects of VIBE on human epidermal cells warrant further investigation, especially in light of the increasing rates of skin and other cancers in the human population.

Phytonutrients have been shown to protect human skin from the cancer-causing effects of UVR, and EGCG has been shown to reduce the damaging effects of UVR when EGCG is applied directly to the skin $[9,11,15,16]$, and also when administered orally to animals [17] and humans [12]. Of interest, human population-based, case-control studies suggested regional differences in the incidence of squamous cell carcinoma of the skin that may be related to tea consumption $[18,19]$. Thus, the beneficial effects of VIBE seen in this experiment will likely extend to the oral administration of VIBE (Figs. 3 and 4).

In addition, to protecting the skin against the damaging and carcinogenic effects of UVR, EGCG may decrease the risk of developing a wide variety of other cancers $[4,20]$ and EGCG appears to be safe and well-tolerated [21]. As suggested by studies investigating the antimutagenic and anti-neoplastic properties of orally ingested tea catechins and fruit and vegetable components, VIBE may also enhance cellular defense mechanisms against other mutagenic freeradical-generating substances [22-26].

Fruit and vegetable consumption has been associated with a decreased incidence of cancer and cardiovascular disease, and bioactive compounds have been extracted from fruits and vegetables; however, a beneficial relationship may exist between the recognized RDA (recommended daily allotment) nutrients and the additional phytonutrients that are found in the whole food matrix which may be lost during the extraction process. Recent evidence supports this idea that combinations of phytochemicals may be far more effective than isolated compounds for cancer protection [23]. The synergy between the various cofactors in the whole fruits and vegetables may be far more effective than the isolated bioactive nutrients that have been studied to date. This cofactor synergy may explain why VIBE, which contains the natural extracts from numerous fruits and vegetables, is so effective at protecting DNA against UVR induced damage in this COMET assay. Due to the significant role free radicals play in the cellular mechanism of the pro-carcinogenic processes and other degenerative conditions, additional research is recommended.

In conclusion, the liquid multi-phytonutrient dietary supplement, VIBE, protected cultured human epidermal cells against UVR-induced DNA damage. Future studies should evaluate the beneficial potential of this product following long-term oral administration.

Acknowledgements The study was designed, conducted and the data were collected, analyzed and interpreted at the independent testing facility, Cancer Chemoprevention Core Laboratory, Linus Pauling Institute (Oregon State University, Corvallis, OR). Funding was provided by Eniva Nutraceuticals.

Open Access This article is distributed under the terms of the Creative Commons Attribution Noncommercial License which permits any noncommercial use, distribution, and reproduction in any medium, provided the original author(s) and source are credited.

\section{References}

1. Rigel DS (2008) Cutaneous ultraviolet exposure and its relationship to the development of skin cancer. J Am Acad Dermatol 58:S129-S132. doi:10.1016/j.jaad.2007.04.034

2. Wischermann K, Popp S, Moshir S, Scharfetter-Kochanek K, Wlaschek M, de Gruijl F, Hartschuh W, Greinert R, Volkmer B, Faust A, Rapp A, Schmezer P, Boukamp P (2008) UVA radiation causes DNA strand breaks, chromosomal aberrations and tumorigenic transformation in $\mathrm{HaCaT}$ skin keratinocytes. Oncogene 31:4269-4280. doi:10.1038/onc.2008.70

3. Marrot L, Meunier JR (2008) Skin DNA photodamage and its biological consequences. J Am Acad Dermatol 58:S139-S148. doi:10.1016/j.jaad.2007.12.007

4. Cabrera C, Artacho R, Giménez R (2006) Beneficial effects of green tea-a review. J Am Coll Nutr 25:79-99

5. Song XZ, Xia JP, Bi ZG (2004) Effects of (-)-epigallocatechin-3gallate on expression of matrix metalloproteinase- 1 and tissue inhibitor of metalloproteinase-1 in fibroblasts irradiated with ultraviolet A. Chin Med J (Engl) 117:1838-1841

6. Xia J, Song X, Bi Z, Chu W, Wan Y (2005) UV-induced NF-kappa B activation and expression of IL- 6 is attenuated by (-)-epigallocatechin-3-gallate in cultured human keratinocytes in vitro. Int J Mol Med 16:943-950

7. Yang SW, Lee BR, Koh JW (2007) Protective effects of epigallocatechin gallate after UV irradiation in cultured human retinal pigment epithelial cells. Korean J Ophthalmol 21:232-237. doi:10.3341/kjo.2007.21.1.48

8. Bae JY, Choi JS, Choi YJ, Shin SY, Kang SW, Han SJ, Kang YH (2008) (-)-Epigallocatechin gallate hampers collagen destruction and collagenase activation in ultraviolet-B-irradiated human dermal fibroblasts: involvement of mitogen-activated protein kinase. Food Chem Toxicol 46:1298-1307. doi:10.1016/j.fct.2007.09.112

9. Elmets CA, Singh D, Tubesing K, Matsui M, Katiyar S, Mukhtar H (2001) Cutaneous photoprotection from ultraviolet injury by 
green tea polyphenols. J Am Acad Dermatol 44:425-432. doi:10.1067/mjd.2001.112919

10. Chung FL, Schwartz J, Herzog CR, Yang YM (2003) Tea and cancer prevention: studies in animals and humans. J Nutr 133:3268S-3274S

11. Katiyar SK (2003) Skin photoprotection by green tea: antioxidant and immunomodulatory effects. Curr Drug Targets Immune Endocr Metabol Disord 3:234-242. doi:10.2174/1568008033340171

12. Morley N, Clifford T, Salter L, Campbell S, Gould D, Curnow A (2005) The green tea polyphenol (-)-epigallocatechin gallate and green tea can protect human cellular DNA from ultraviolet and visible radiation-induced damage. Photodermatol Photoimmunol Photomed 21:15-22. doi:10.1111/j.1600-0781.2005.00119.x

13. Ostling O, Johanson KJ (1984) Microelectrophoretic study of radiation-induced DNA damages in individual mammalian cells. Biochem Biophys Res Commun 123:291-298. doi:10.1016/0006291X(84)90411-X

14. Szeto YT, Benzie IF (2002) Effects of dietary antioxidants on human DNA ex vivo. Free Radic Res 36:113-118. doi:10.1080/ 10715760210161

15. Katiyar SK, Afaq F, Perez A, Mukhtar H (2001) Green tea polyphenol (-)-epigallocatechin-3-gallate treatment of human skin inhibits ultraviolet radiation-induced oxidative stress. Carcinogenesis 22:287-294. doi:10.1093/carcin/22.2.287

16. Linden KG, Carpenter PM, McLaren CE, Barr RJ, Hite P, Sun JD, Li KT, Viner JL, Meyskens FL (2003) Chemoprevention of nonmelanoma skin cancer: experience with a polyphenol from green tea. Recent Results Cancer Res 163:165-171

17. Katiyar S, Elmets CA, Katiyar SK (2007) Green tea and skin cancer: photoimmunology, angiogenesis and DNA repair. J Nutr Biochem 18:287-296. doi:10.1016/j.jnutbio.2006.08.004
18. Hakim I, Harris R, Weisgerber U (2000) Tea intake and squamous cell carcinoma of the skin: Influence of type of tea beverages. Cancer Epidemiol Biomarkers Prev 9:727-731

19. Hakim IA, Harris RB (2001) Joint effects of citrus peel use and black tea intake on the risk of squamous cell carcinoma of the skin. BMC Dermatol 1:3. doi:10.1186/1471-5945-1-3

20. Shanafelt TD, Lee YK, Call TG, Nowakowski GS, Dingli D, Zent CS, Kay NE (2006) Clinical effects of oral green tea extracts in four patients with low grade B-cell malignancies. Leuk Res 30:707-712. doi:10.1016/j.leukres.2005.10.020

21. Chow HH, Cai Y, Hakim IA, Crowell JA, Shahi F, Brooks CA, Dorr RT, Hara Y, Alberts DS (2003) Pharmacokinetics and safety of green tea polyphenols after multiple-dose administration of epigallocatechin gallate and polyphenon $\mathrm{E}$ in healthy individuals. Clin Cancer Res 9:3312-3319

22. Khan N, Afaq F, Mukhtar H (2008) Cancer chemoprevention through dietary antioxidants: progress and promise. Antioxid Redox Signal 10:475-510. doi:10.1089/ars.2007.1740

23. de Kok TM, van Breda SG, Manson MM (2008) Mechanisms of combined action of different chemopreventive dietary compounds: a review. Eur J Nutr 47(Suppl 2):51-59. doi:10.1007/s00394-0082006-y

24. Wasson GR, McKelvey-Martin VJ, Downes CS (2008) The use of the comet assay in the study of human nutrition and cancer. Mutagenesis 23:153-162. doi:10.1093/mutage/gen003

25. Seifried HE, Anderson DE, Fisher EI, Milner JA (2007) A review of the interaction among dietary antioxidants and reactive oxygen species. J Nutr Biochem 18:567-579. doi:10.1016/j.jnutbio.2006.10.007

26. Zhang M, Holman CD, Huang JP, Xie X (2007) Green tea and the prevention of breast cancer: a case-control study in Southeast China. Carcinogenesis 28:1074-1078. doi:10.1093/carcin/bg1252 